УДК [37.015.31: 172]: 061.2

DOI: https://doi.org/10.35619/iiu.v0i9.133

Ціпан Тетяна

кандидат педагогічних наук, доцент, доцент кафедри теорії і методики виховання

Рівненського державного гуманітарного університету,

м. Рівне, Україна

ORCID: 0000-0002-1356-2825

e-mail:23ttss22@ukr.net

\title{
ФОРМУВАННЯ ГРОМАДЯНСЬКОЇ ПОЗИЦІЇ У ЧЛЕНІВ ДИТЯЧО-ЮНАЦЬКИХ ГРОМАДСЬКИХ ОБ'ЄДНАНЬ
}

\begin{abstract}
Анотація. У статті обгрунтовано актуальність проблеми громадянського виховання підростаючого покоління в нинішніх соціально-політичних умовах розвитку країни. Схарактеризовано низку вітчизняних нормативно-правових документів щодо визначення мети, завдань, форм та методів організації національно-патріотичного, громадянського виховання зростаючої особистості як в освітньо-виховних закладах, так і громадських об'єднаннях.

Розглянуто тлумачення поняття «громадянська позиція» у суміжних 3 ним поняттях «громадянин», «громадянськість», «позиція», «громадянська позиція». 3'ясовано, що громадянська позиція формується в межах загальнолюдської позиції і в міру розвитку особистості займає все більш значуще, провідне місце в іï структурі. Ядром поняття «громадянська позиція» $є$ громадянська свідомість особистості, яка, органічно поєднуючись з моральними почуттями, виражається у вчинку, в активній діяльності, спрямованій на утвердження поглядів та ідеалів. Запропонований авторський погляд на процес формування громадянської позиції у членів дитячих громадських об'єднань, кінцевим результатом якого має стати сформована інтегрована якість, що характеризує особистість як свідомого члена суспільства зі сформованою громадянською свідомістю, громадянським обов'язком, готовністю працювати на загальну користь, відповідальністю і умінням поєднувати особисті і громадські інтереси, відстоювати інтереси держави.

Схарактеризовано фактори формування громадянської позиції у членів дитячо-юнацьких об'єднань (ідеологічний, маніпулювання свідомістю, інформаційного впливу) та його етапи (початковий, основний, пролонгований).

Увага акцентована на застосуванні форм і методів, що грунтуються на активності та демократичному стилі взаємодії, спрямовані на самостійний пошук істини, формування критичного мислення, ініціативності й творчості, відповідальності.
\end{abstract}

Ключові слова: громадянська позиція, громадянська свідомість, член дитячоюнацького громадського об’єднання, соціально значуща діяльність.

Постановка проблеми. Завдання громадянського та патріотичного становлення молодого покоління $\epsilon$ важливим для будь-якої держави. Особливого значення ця проблема набуває у період загострення політичної ситуації в країні, військової загрози, яка наразі існує в країні, зміни ідеалів, переорієнтації цінностей. Все це суттєво впливає на процес формування громадянської позиції дітей і молоді. Від того наскільки сформовані у дітей та молоді почуття-цінності «Я-Українець» - «Ми-Українці» залежить рівень 
сформованості у них громадянської позиції сьогодні і шлях подальшого розвитку нашого суспільства в майбутньому.

Аналіз останніх досліджень 3 проблеми. Соціальне замовлення держави в освіті спрямоване на виховання людини освіченої, духовно здорової і морально вихованої, суспільно активної, готової самостійно приймати рішення в ситуації вибору, здатної до співпраці і взаємодії, тобто такої, у якої сформована громадянська позиція. Це знаходить своє підтвердження в низці нормативно-правових документах: Конституції України, законах України «Про освіту», «Про загальну середню освіту», «Про сприяння соціальному становленню та розвитку молоді в Україні», «Про молодіжні та дитячі громадські організації», Національній доктрині розвитку освіти, Концепції національно-патріотичного виховання дітей і молоді, Основних орієнтирах виховання учнів 1-11 класів загальноосвітніх навчальних закладів України, Стратегії національно-патріотичного виховання дітей та молоді на 2016-2020 роки, Концепції формування у підлітків національно-культурної ідентичності у загальноосвітніх навчальних закладах, Концепції «Нова українська школа», Концепції розвитку громадянської освіти в Україні, Глобальній програмі дій 3 освіти в інтересах сталого розвитку та інших.

Зокрема, у Національній доктрині розвитку освіти (2002) наголошено, що домінантною основою розвитку українського суспільства $\epsilon$ виховання «свідомого громадянина, патріота, набуття молоддю соціального досвіду, високої культури міжнаціональних взаємовідносин, формування в молоді потреби та уміння жити в громадянському суспільстві, духовності та фізичної досконалості, моральної, художньо-естетичної, трудової, екологічної культури».

Стратегія національно-патріотичного виховання дітей та молоді на 20162020 роки (Міністерство освіти і науки України, 2015) акцентує увагу на необхідності формування в зростаючої особистості активної громадянської позиції та національно-патріотичної свідомості. У документі визначено, що розвиток громадянина як високоморальної особистості, яка плекає українські традиції, духовні цінності, володіє відповідними знаннями, вміннями та навичками, здатна реалізувати свій потенціал в умовах сучасного суспільства, має стати одним із пріоритетних напрямів діяльності держави та суспільства.

Згідно 3 Концепцією розвитку громадянської освіти в Україні (Міністерство освіти і науки України, 2018) метою громадянської освіти $\epsilon$ формування і розвиток у громадян України громадянських компетентностей, спрямованих на утвердження і захист державності та демократії, здатності відстоювати свої права, відповідально ставитися до громадянських обов'язків, брати відповідальність за своє власне життя, за налагодження гармонійних стосунків між членами своєї сім'ї, за життя територіальної громади.

Поставлені в документах завдання активізували педагогічні дослідження з вищезазначеної проблеми.

Різні аспекти громадянського виховання відображені в наукових працях сучасних вчених П. Вербицької, В. Вербицького, С. Диби, Н. Жданович, Ю. Завалевського, С. Кириленко, О. Кіян, О. Сухомлинської, І. Тараненко, які здійснили істотний внесок у теорію і практику громадянського виховання підростаючого покоління під час організації освітньо-виховного процесу в школі, організації позакласної виховної роботи, діяльності позашкільних освітньо-виховних закладів. Однак, аспекту формування громадянської позиції 
членів дитячо-юнацьких громадських об'єднань приділено недостатньо уваги, i цим пояснюється визначення мети нашого дослідження.

Виклад основного матеріалу дослідження. Розглянемо тлумачення поняття «громадянська позиція» у суміжних 3 ним поняттях «громадянин», «громадянськість», «позиція», що представлені в Концепції громадянського виховання особистості в умовах розвитку української державності (Академія педагогічний наук України, 2000).

Громадянин - людина, яка ідентифікує себе з певною країною, у якій вона наділена відповідним юридичним статусом, що $\epsilon$ підставою для користування певними правами, а також дотримання обов'язків.

Громадянськість - духовно-моральна цінність, світоглядно-психологічна характеристика людини, що зумовлена іiї державною самоідентифікацією, усвідомленням належності до конкретної країни.

Позиція - рефлексивне ставлення суб'єкта, що грунтується на особистісно значущих цінностях, і проявляється в діяльності. Позиція в першу чергу - це характеристика активності особистості, її суб'єктності.

Громадянська позиція - система ціннісних і соціальних орієнтацій та настановлень, які характеризують людину як громадянина країни та суспільства.

Громадянська позиція формується в межах загальнолюдської позиції і в міру розвитку особистості займає все більш значуще місце в ії структурі. Вона характеризує особистість з точки зору способу і характеру взаємин 3 певною дійсністю. Це поняття відображає політичні, юридичні, моральні права i обов'язки громадян стосовно своєї держави i передбачає свідоме, відповідальне ставлення людей до суспільства. Ядром поняття «громадянська позиція» є громадянська свідомість особистості, яка, органічно поєднуючись 3 моральними почуттями, виражається у вчинках, в активній діяльності, спрямованій на утвердження поглядів та ідеалів.

У психолого-педагогічній літературі розглядається два варіанти громадянської позиції: внутрішня позиція (ціннісно-змістова сфера особистості), що проявляється в іiі мотивах і спрямованості, сформованій громадянській свідомості і розвинутих громадянських почуттях і зовнішня позищія (сукупність стратегій громадянської поведінки). Становлення i розвиток громадянської позиції відбувається на основі сформованих особистісних якостей громадянина: громадянської активності, громадянської мужності, громадянської відповідальності, громадянської гідності, незалежності переконань, патріотизму.

Становлення громадянської позиції зростаючої особистості - тривалий i безперервний процес, який здійснюється в умовах навчальних закладів, закладів позашкільної освіти, дитячо-юнацьких та молодіжних громадських організаціях та об'єднаннях. Дитячо-юнацькі громадські об'єднання з одного боку орієнтовані на задоволення інтересів і потреб зростаючої особистості, 3 іншого - володіють усіма можливостями для виховання своїх членів ініціативними та активними громадянами країни, формуванню таких сторін життєвого досвіду, яких в інших виховних інституціях вони не завжди можуть отримати (наприклад, брати участь у прийнятті важливих для них рішень, оволодівати демократичними принципами співжиття в громадянському суспільстві), сприяють їх самовираженню відповідно до тієї позиції, яку вони займають у дитячому формуванні. 
У зв'язку 3 цим позиція члена дитячо-юнацького громадського об'єднання співвідноситься 3 тією соціальною роллю, яку він виконує в колективі дитячого громадського формування.

Згідно з соціологічними опитуваннями Т. Окушко (ред., 2018) факторами впливу на формування громадянської позиції та патріотичних почуттів членів громадських об'єднань учнівської молоді є: сім'я - 97,9 \%; навчальні заклади 94\%; інтернет-комунікації - 88,3 \%; ЗМІ - 84 \% ; громадські організації - 83\%.

Як бачимо, громадським організаціям відведено значне місце в системі формування громадянської позиції дітей та молоді. Тому, формування громадянської позиції членів дитячих громадських об'єднань ми визначаємо як цілеспрямований, безперервний, спеціально організований процес соціально важливої громадської діяльності, що передбачає засвоєння знань про громадянське суспільство (когнітивний компонент), формування ціннісних ставлень (ціннісно-орієнтаційний компонент) та оволодіння досвідом громадянської поведінки (функціонально-діяльнісний компонент).

Кінцевим результатом процесу формування громадянської позиції ми вважаємо сформовану інтегровану якість кожного члена дитячо-юнацького громадського об'єднання, що характеризує його як свідомого члена суспільства зі сформованими громадянською свідомістю та громадянським обов'язком, готовністю працювати на загальну користь, відповідальністю і умінням поєднувати особисті і громадські інтереси, відстоювати інтереси держави, непримиренністю до антигромадських і антидержавних проявів.

Для досягнення кінцевого результату важливим $є$ врахування факторів, означених в Програмі «Нова українська школа» у поступі до цінностей (Національна академія педагогічних наук України, Інститут проблем виховання, державна наукова установа «Інститут модернізації змісту освіти», 2018):

- ідеологічний фактор, який ставить за мету убезпечити молодь від впливу ідеології інших держав, зацікавлених у формуванні своїх прихильників та розхитуванні з середини політичної ситуації в Україні. На сьогодні $\epsilon$ потреба у тому, щоб повернути українській ідеології ії власні: зміст, потенціал, історію, пантеон героїв і визначних діячів, переосмислити існуючий досвід i визначити новітні завдання подальшого розвитку нації, держави, суспільства;

- фактор маніпулювання свідомістю активно здійснюється через засоби масової інформації, різного роду інформаційні ресурси, які є потужним засобом впливу на молодь та використовуються різними країнами 3 метою впливу на неї, роздмухування сепаратистських настроїв, презирливого ставлення до своєї Батьківщини, іiі культурних здобутків. Масована підміна національних архетипів масовою культурою є причиною відсутності стійких моральних цінностей та зорієнтованістю на ціннісно-примітивну субкультуру, збіднення власного духовного світу;

- фактор інформаційного впливу. Інформаційна війна з боку Російської Федерації загрожує деформацією ціннісних основ, морально-духовної єдності українського суспільства в боротьбі проти проросійських терористів на Сході країни. Це вимагає підвищення ефективності національно-патріотичного та військово-патріотичного виховання підростаючого покоління, здатного до гідного захисту територіальної цілісності країни зі зброєю в руках. 
Дефініційний аналіз поняття «громадянська позиція» дає нам можливість окреслити етапи процесу становлення громадянської позиції у членів дитячоюнацьких громадських об'єднань:

1. Початковий етап - залучення членів дитячо-юнацьких громадських об'єднань до цілеспрямованої суспільно-значущої діяльності, реалізація їх творчого потенціалу. На цьому етапі закладаються основні моральні цінності, засвоюються норми поведінки, моральні вимоги і зобов'язання перед суспільством і державою (громадянський обов'язок). Починається формування особистості, яка усвідомлює себе частиною суспільства і громадянином своєї Вітчизни. Відбувається усвідомлення свого значення та ролі в житті суспільства і держави (громадянська самосвідомість). Головне завдання цього етапу - розвиток громадянського потенціалу - формування особистості, здатної здійснити свій внесок у життя громади, краю, країни.

2. Основний етап - вироблення стійкої лінії поведінки; розвиток умінь критично мислити, здобувати, аналізувати інформацію, отриману з різних джерел; використання знань для розв'язання життєвих проблем; генерування нових ідей; розвиток навичок приймати нестандартні рішення й нести за них відповідальність; оволодіння комунікативною культурою, уміння працювати в команді, розв'язувати конфліктні ситуації; цілеспрямовано використовувати свій потенціал для самореалізації як в особистому, так і суспільному житті; розвиток здібностей, пов'язаних з необхідністю подальшої освіти в постійно змінюючих соціальних умовах.

Стрижнем становлення громадянської позиції $є$ практична участь членів об'єднання у вирішенні соціальних завдань (громадянська активність), а також ті здатності особистості, що дозволяють їй активно, відповідально і ефективно реалізовувати комплекс громадянських прав і обов'язків, застосовувати наявні знання і вміння на практиці (громадянська компетентність).

3. Пролонгований етап - сприяння формуванню та актуалізація системи суспільних знань і практичних навичок. Завдання етапу - вдосконалення готовності і вміння відстоювати свої права та захищати права інших людей, вміння вибудовувати індивідуальну та колективну діяльність. У процесі освітньо-пізнавальної, ціннісної та практичної діяльності у членів дитячоюнацьких громадських об'єднань поглиблюються, розширюються знання про процеси, що відбуваються в різних сферах суспільства; триває процес пізнання культурних, політико-правових та соціально-економічних основ життя суспільства. Відбувається підвищення рівня знань громадянознавчого характеру шляхом ознайомлення із нормативними документами всеукраїнського і регіонального рівнів; формуються уміння відстоювати свої права і точку зору (політична культура); триває процес формування поваги до закону, права, відповідальності перед суспільством, оволодіння формами участі в суспільно-політичному житті (правова культура).

Властива членам дитячо-юнацьких громадських об'єднань соціальна спрямованість діяльності дозволяє уявити процес становлення їх громадянської позиції у вигляді сукупності теоретичних і практичних завдань, під час вирішення яких кожен член об'єднання стає «суб'єктом» суспільнозначущої діяльності.

Головне завдання планування діяльності дитячо-юнацьких громадських об'єднань щодо формування громадянської позиції - наповнити інтереси дітей і підлітків соціально значущим змістом, що грунтується на досвіді поколінь, 
допомогти їм засвоїти і оволодіти цим досвідом, перетворюючи оточуюче життя на краще $з$ позиції громадянина.

Зміст роботи по формуванню в членів дитячо-юнацьких громадських об'єднань громадянської позиції включає: виховання почуття відповідальності; розвиток національної самосвідомості; формування відповідальності за долю Батьківщини; озброєння знаннями про свої права і обов'язки, формування потреби використовувати свої права i дотримуватися своїх обов'язків; стимулювання громадської, економічної, трудової, природоохоронної, соціальної активності; розвиток поваги до законів держави, готовність виконувати їх і на цій основі формування правосвідомості, законослухняності і високого почуття патріотизму.

Ефективність різних видів виховання залежить від спрямованості виховного процесу, форм і методів його організації. При цьому слід пам'ятати, що форми виховної роботи в громадських об'єднаннях повинні відрізнятися від тих, що організовуються в школі. Відповідно до реалізації змісту вони повинні відповідати тим ролям, які члени дитячо-юнацьких об'єднань виконують в сім’ї (син, дочка, онук, онука, брат, сестра, родичі); в дитячому об'єднанні ( член об'єднання, лідер); в соціумі (друг, сусід, член об'єднання; в Батьківщині (патріот, захисник, трудівник); на планеті (миротворець, еколог, культуролог). Незалежно від форми роботи в їх змісті основу складають правові норми, які передбачають відповідальність перед самим собою, оточуючими людьми, Батьківщиною.

Серед розмаїття форм виховної роботи виокремлюємо такі, що грунтуються на активності та демократичному стилі взаємодії, спрямовані на самостійний пошук істини, формування критичного мислення, ініціативності й творчості, відповідальності: квести, ярмарки солідарності, конкурси, турніри, рольові та ділові ігри, пошукові ігри, брейн-сторми, диспути, дебати, консультування, моделювання, доброчинні акції та проекти, флешмоби, форуми, скайп-конференції, онлайн-спілкування, майстер-класи, табори та вишколи тощо.

Серед методів формування громадянської позиції ефективними є: наративні методи, метод «моральних дилем», кластерний метод (складання кросвордів, схем, таблиць, діаграм), рефлексивний, вирішення проблемних ситуацій, метод особистісної репрезентації, методи різнонаукового бачення, «Open space», «Світове кафе», методи формування і корекції свідомості особистості.

Одним 3 інтенсивних методів формування громадянської позиції $\epsilon$ соціальне проектування. Використання методу соціального проектування в діяльності дитячого громадського об'єднання спрямоване на розвиток основних громадянських компетенцій особистості: пізнавальної (виражається в самостійному пошуку та отриманні інформації з різних джерел, умінні іiі аналізувати, критично мислити); суспільно-політичної і правової (полягає в реалізації прав і обов'язків, виконанні функцій громадянина у взаємодії 3 представниками різних соціальних інститутів і владою); морально-етичної (проявляється в особистому удосконаленні людини, умінні визначати i оцінювати свою поведінку, грунтуючись на моральних нормах і правових поняттях, відповідних гуманістичних і демократичних цінностях). У процесі роботи над соціально важливими проектами відбувається згуртування колективу, а учасники проекту залучаються до колективної діяльності, 
набувають можливості на практиці впливати на соціальне середовище. Крім того, участь у реалізації проекту є формою встановлення нових контактів, наприклад, 3 представниками громадських i державних структур, 3 працівниками засобів масової інформації.

Під час безпосередньої практичної діяльності відбувається актуалізація опорних знань, розвиток пізнавальних можливостей, формування умінь, творчого підходу до діяльності, емоційно-ціннісного ставлення до соціально значущої діяльності. Учасники соціального проекту отримують досвід: підготовки i здійснення соціально значущих справ (турбота про людей похилого віку та інвалідів, шефство над дитячими будинками, соціальними інтернатами, дитячими садами, учнями молодших класів та ін.); розробки соціальних проектів та їх реалізацію в межах школи, району, міста; спільної реалізації соціальних проектів з учасниками інших громадських об'єднань i соціальними інститутами; участі в благодійних акціях; участі в заходах 3 охорони природи і пам'ятників культури.

Висновки і перспективи подальших розвідок. Громадянська позиція $\epsilon$ відображенням усього розмаїття суспільного життя особистості і здійснює вирішальний вплив на утвердження соціального статусу громадянина. Рівень громадянської позиції визначає загальнокультурний рівень розвитку особистості i, як наслідок, цивілізоване функціовання громадянського суспільства і держави в цілому.

Громадянська позиція члена дитячого громадського об'єднання $\epsilon$ важливим компонентом, який забезпечує його активність як суб'єкта всіх соціально-економічних, політичних перетворень у державі, тому забезпечує формування демократичного, суверенного суспільства, передбачає усвідомлене та відповідальне ставлення до суспільства, уміння орієнтуватися в сучасному світі, планувати свої дії, прогнозувати результати й відповідати за прийняття тих чи інших рішень. Проявом громадянської позиції особистості є їі ставлення до суспільства, до дійсності, до людей, до самої себе, яке проявляється у соціально значущій діяльності. Важливим при цьому є підготовка керівників дитячих громадських об'єднань 3 організації громадянського виховання, в чому і вбачаємо перспективу подальших наукових досліджень.

\section{СПИСОК ВИКОРИСТАНИХ ДЖЕРЕЛ:}

Міністерство освіти і науки України (2002). Національна доктрина розвитку освіти Украӥни. Режим доступу: http://zakon0.rada.gov.ua/laws/show/347/2002. [Дата звернення 6 квітня 2019].

Міністерство освіти і науки України. (2015). Стратегія національнопатріотичного виховання дітей та молоді. Режим доступу: http://zakon3.rada.gov.ua/laws/show/580/2015. [ Дата звернення 12 квітня].

Міністерство освіти i науки України. (2018). Концепція розвитку громадянської освіти в Україні. Режим доступу: https://zakon.rada.gov.ua/laws/show/710-2018-p?lang=r [Дата звернення 12 квітня].

Академія педагогічних наук України. (2000). Концепція громадянського виховання особистості в умовах розвитку украӥнської державності. Режим доступу: 4http://osvita.khpg.org/index.php?id=976002302. [Дата звернення 12 квітня].

Окушко, Т. (наук. ред.). (2018). Особистісно орієнтовані технологї національно-патріотичного виховання учнівської молоді в громадських об'єднаннях : метод. посіб. К., Кропивницький : Імекс-ЛТД. 198 с. 
Національна академія педагогічних наук України, Інститут проблем виховання, державна наукова установа «Інститут модернізації змісту освіти». (2018). Програма «Нова українська школа» у поступі до циінностей. Режим доступу : програма-02-08-2018_ІПВ НАПН. [Дата звернення 15 квітня].

Nieuwelink, H., Dam, G. \& Dekker, P. (2018). Adolescent Citizenship and Educational Track: A Qualitative Study on the Development of Views on the Common Good. Journal: Research Papers in Education. doi: [10.1080/02671522.2018.1452958] Wood, J. (2009). Young People and Active Citizenship: An Investigation Thesis submitted in partial fulfillment of the requirements for the award of Doctor of Philosophy (PhD) De Montfort University De Montfort University August 2009 - Retrieved fromhttps://core.ac.uk/download/pdf/2748417.pdf

Окушко, Т., Петрочко, Ж., Чиренко, Н., Шпиг, Н., Пащенко, О. та ін. (2015). Формування сочіальної ініціативності підлітків у дитячому об'єднанні: монографія. - Харків: «Друкарня Мадрид», 2015. - 318 с.

Ціпан, Т. (2012). Педагогічні умови громадянського виховання підлітків у дитячо-юнацьких об'єднаннях. Автореферат дис. канд. пед. наук. - Харків: Харківський національний університет імені В. Н. Каразіна. 22 с.

\section{REFERENCES:}

Ministerstvo osvity i nauky Ukrainy (2002). Natsionalna doktryna rozvytku osvity Ukrainy. [National Doctrine of the Development of Education of Ukraine] Rezhym dostupu: http://zakon0.rada.gov.ua/laws/show/347/2002. [Data zvernennia 6 kvitnia 2019]. [in Ukrainian]

Ministerstvo osvity i nauky Ukrainy. (2015). Stratehiia natsionalno-patriotychnoho vykhovannia ditei ta molodi [Strategy of National-patriotic Education of Children and Youth] Rezhym dostupu: http://zakon3.rada.gov.ua/laws/show/580/2015. [Data zvernennia 12 kvitnia]. [in Ukrainian]

Ministerstvo osvity i nauky Ukrainy. (2018). Kontseptsiia rozvytku hromadianskoi osvity v Ukraini [Concept of Development of Civic Education in Ukraine] Rezhym dostupu: https://zakon.rada.gov.ua/laws/show/710-2018-r?lang=r [Data zvernennia 12 kvitnia]. [in Ukrainian]

Akademiia pedahohichnykh nauk Ukrainy. (2000). Kontseptsiia hromadianskoho vykhovannia osobystosti v umovakh rozvytku ukrainskoi derzhavnosti [The Concept of Civic Education of a Person in the Conditions of Development of Ukrainian Statehood] Rezhym dostupu: http://osvita.khpg.org/index.php?id=976002302. [Data zvernennia 12 kvitnia]. [in Ukrainian]

Okushko, T. (the ed.). (2018). Osobystisno oriientovani tekhnolohii natsionalnopatriotychnoho vykhovannia uchnivskoi molodi $v$ hromadskykh obiednanniakh : metod. posib. [Personally oriented technologies of national-patriotic education of student youth in public associations: method. manual] K., Kropyvnytskyi : Imeks-LTD. 198 s. [in Ukrainian]

Natsionalna akademiia pedahohichnykh nauk Ukrainy, Instytut problem vykhovannia, derzhavna naukova ustanova "Instytut modernizatsii zmistu osvity". (2018). Prohrama "Nova ukrainska shkola" u postupi do tsinnostei [The Program "New Ukrainian School" in Advancing Values]. Rezhym dostupu : prohrama-02-08-2018_IPV NAPN. [Data zvernennia 15 kvitnia]. [in Ukrainian]

Nieuwelink, H., Dam, G. \& Dekker, P. (2018). Adolescent Citizenship and Educational Track: A Qualitative Study on the Development of Views on the Common Good. In Research Papers in Education.

Wood, J. (2009). Young People and Active Citizenship: An Investigation Thesis submitted in partial fulfillment of the requirements for the award of Doctor of Philosophy 
(PhD) De Montfort University De Montfort University August 2009 - Retrieved from https://core.ac.uk/download/pdf/2748417.pdf

Okushko, T., Petrochko, Zh., Chyrenko, N., Shpyh, N., Pashchenko, O. ta in. (2015). Formuvannia sotsialnoi initsiatyvnosti pidlitkiv $u$ dytiachomu obiednanni: monohrafiia [Formation of Social Initiative of Adolescents in a Children Association: monograph] - Kharkiv: "Drukarnia Madryd", 2015. - 318 s. [in Ukrainian]

Tsipan, T. (2012). Pedahohichni umovy hromadianskoho vykhovannia pidlitkiv $u$ dytiacho-yunatskykh obiednanniakh. [Pedagogical Conditions of Civic Education of Adolescents in Children and Youth Associations]. Candidate Pedagogical Sciences. Kharkivskyi natsionalnyi universytet imeni V. N. Karazina. 22 c. [in Ukrainian]

\title{
FORMATION OF CIVIC STAND AMOMG MEMBERS OF CHILDREN AND YOUTH ASSOCIATIONS
}

\author{
Tetiana Tsipan \\ Candidate of Pedagogical Sciences, Associate Professor, \\ Associate Professor at the Department of \\ Theory and Methods of Education, \\ Rivne State University of the Humanities, \\ Rivne, Ukraine \\ ORCID: 0000-0002-1356-2825 \\ e-mail: 23ttss22@ukr.net
}

\begin{abstract}
The article deals with the problem of civic education of the younger generation in the current socio-political conditions of the country's development. An amount of Ukrainian legal documents on the definition of goals, tasks, forms and methods of organization of national-patriotic, civic education of a growing personality both in educational institutions and public associations are characterized and analyzed.

The interpretation of the concept "civic position" in the adjacent concepts of "citizen", "citizenship", "position", "civic position" is considered. It is found out that the civil stand is formed regarding to the common human position and as the personality develops, it is becoming more and more important in its structure. The core of the concept "civic position" is the civic consciousness of the individual, which, organically combined with moral feelings, is expressed in the act, in an active activity aimed at strengthening views and ideals.

The author's opinion on the process of formation of a civic stand among the members of children public associations is proposed, the final result of which should be the formed integrated quality, that characterizes the personality as a member of the society with a formed civic consciousness, civic duty, willingness to work for common good, responsibility and ability to combine personal and public interests, defend the interests of the state, a person with a formed intransigence to anti-social and anti-state manifestations.

The factors of formation of a civic stand (ideological, consciousness manipulation, information influence) and its stages (initial, main, prolonged) in the conditions of children and youth associations are characterized.

Attention is focused on the use of active and democratic forms and methods of education aimed at the independent search for truth, the formation of critical thinking, initiative and creativity, responsibility.

Key words: civic stand, civic consciousness, member of children and youth public association, civic activity.
\end{abstract}

Стаття надійшла до редакиії 06.05.2019p. 